\title{
Influence of the rainfall in the content of nutrients in litter in agroforestry systems managed with burning and without burning in Amazon
}

\author{
Rosecélia Moreira Da Silva Castro ${ }^{1^{*}}$, Maria De Lourdes Pinheiro Ruivo ${ }^{2}$, Jorge Luiz Piccinin ${ }^{2}$, \\ Eraldo Ferreira Rodrigues ${ }^{3}$ \\ ${ }^{1}$ Federal University of Rural Amazonia, Institute Sciences Agricultural, Belém, Brasil; \\ *Corresponding Author: rmsilva@museu-goeldi.br \\ ${ }^{2}$ Emilio Goeldi Pará Museum, Coordination of Earth Sciences and Ecology, Belém, Brasil \\ ${ }^{3}$ Brazilian Company of Agricultural Research, Statistical Department, Belém, Brasil
}

Received 4 September 2013; revised 5 October 2013; accepted 16 October 2013

Copyright (C) 2013 Rosecélia Moreira Da Silva Castro et al. This is an open access article distributed under the Creative Commons Attribution License, which permits unrestricted use, distribution, and reproduction in any medium, provided the original work is properly cited.

\section{ABSTRACT}

This study evaluated the nutrient content of the litter, testing different treatments with burning and no burning, of the vegetation, to identify which one provides better efficiency in operation and production of nutrients in different seasonal conditions. The study area is located on the property of the family farmer, initially selected by a diagnosis socioeconomic, community Benjamin Constant, in northeastern Para. Litter was collected during two periods: dry season (November) and rainy (March) in 2009. For the collection of litter samples, we used collectors measuring $\left(0.25 \times 0.25 \mathrm{~m}^{2}\right)$, which were placed directly on the soil surface. The collected material was stored in paper bags and taken to the laboratory for Chemical Analysis of the Brazilian Agricultural Research Corporation (EMBRAPA), which was determined by analyses of macronutrients ( $\mathrm{N}, \mathrm{P}, \mathrm{K}, \mathrm{Ca}, \mathrm{Mg}, \mathrm{Na}$ ) and micronutrients (Fe, $\mathrm{Cu}, \mathrm{Mn}, \mathrm{Zn})$. The highest concentrations of macronutrients were found in $\mathrm{N}$ for agroforestry systems with and without burning in two seasons (wet and dry). All macronutrients showed influence of seasonality, which was verified by the wide variation in nutritional behavior. The decreasing concentration of nutrients was presented $\mathrm{N}>\mathrm{Ca}>\mathrm{Mg}>\mathrm{Na}>\mathrm{K}>\mathrm{P}$ in agroforestry system with burning, with maximum values of all nutrients in the rainy season, and $\mathrm{N}, \mathrm{P}, \mathrm{K}, \mathrm{Ca}, \mathrm{Na}$ in higher concentrations in agroforestry system without burning, and show- ed only the Mg peak in agroforestry system with burning. The behavior of the concentration of nutrients was opposite to that observed one, for all elements analyzed showed a reduction in the concentrations of nutrients in the dry season. The decreasing concentration of nutrients was presented $\mathrm{Fe}>\mathrm{Mn}>\mathrm{Zn}>\mathrm{Cu}$.

Keywords: Forest; Management; Ecosystem; Seasonality; Litterfall

\section{INTRODUCTION}

The use of agroforestry systems has been considered as an optimization alternative to the use of land, because it conceals the forestry production with the aliments, conserving the soil, decreasing the impact caused by agricultural practices and favoring the cycle of nutrients through a higher contribution of litter.

The litter decomposition is the main way of transference of the nutrients to the soil, and it can make possible their re-absorption by the living vegetables [1] through the nutrients cycling, which is responsible for the elements exchange between living beings and the environment around them, focused on the relationship between vegetation and the soil [2].

The litter involves the more superficial surface in agroforestry environments, being made by leaves, branches, reproductive organs and residual deposits that develop several functions to the harmony and the dynamic of these ecosystems. The litter, besides other functions, protects the soil against high temperatures, deposits in its content a great quantity of seeds ready to germinate or in 
dormancy state, shelters a great fauna composed by micro and macro invertebrates that act directly in the process of decomposing these materials and fertilizing. The information generation about the litter deposition and the analysis of its content is an important tool to the comprehension and conservation of these areas, as well as its inter relationships with the environment.

The agroforestry systems (SAFs), even though implanted after the slashing and burning actions suffered by the forests, have been proposed as an alternative to the recovery of degraded areas [3] and the litter produced by the different systems is one of the promoting agents of this recovery. The study of the mineral nutrients cycle is fundamental to know the structure and the function of ecosystems. Part of the organic and nutrients matter returns to the forestry soil, and is considered the most important mean of essential elements transference from the vegetation to the soil [4].

Several studies have been applied in Brazil and in the world objecting the contribution to a better knowledge about the nutrients cycle and the forestry ecosystems dynamic, and even in homogeneous plantations of forestry and agricultural specimens [5] longing to determine the patterns of every vegetable typology and present for this process the differences between them, to create the possibility of a better understanding of the environment mechanism and answers to the anthropic modifications applied in it, and the study of litter production has contributed to a better understanding of the vegetation and soil function in these systems.

The agroforestry systems (SAFs) have been recommended to tropical regions due to environment, economic and social benefits. These benefits are generally related to the carbon kidnap capacity from the atmosphere, adequate water and nutrients cycle, and the development of the soil quality in comparison to annual or perennial mono agriculture [6]. According to the composition and treatment of SAFs, these systems can also keep high diversity of fauna and flora, compared to others agricultural systems.

The importance of micro climate factors in the litter decomposition and production was verified by [7], when it was showed that the light, the temperature, the soil humidity and the nutrients availability are capable of suffering alterations due to the deposited litter quantity. A realized research with the litter production in agroforestry system [8] observed that, although the highest production has had a coincidence with the drought season ending, it couldn't be found a significant correlation between the analyzed climate variations, the same result found by [9] when he realized a study of the climate variation influences on primary forest litter.

The seasonal pattern of litter deposition in the agroforestry system, with a higher production in the end of the drought season, is typical of semideciduous forests, where the leaves deposition peaks, during this period of the year, and happens as an answer of the vegetation to the seasonal climate; data were obtained of total and fractional litter production which are similar to the ones found in semideciduous forests in the southeast of Brazil, what allows to affirm that the system has presented the behavior of a native forest in terms of litter dynamic.

Researchers contemplate the eucalypt consortium with leguminous trees in Brazil. It is clear that the infinity of combinations that the tropical biodiversity offers to work in favor of a sustainable development of the planted forest [10] studied the litter dynamic and the $\mathrm{N}$ transference capacity to the soil in eucalypt plantations. The plantation of Eucalyptus grandis and Pseudosamanea guachapele in sandy soils should be incentivized, because, when it is compared to the eucalypt plantation only, the $\mathrm{N}$ quantity contribution to the soil and the speed of mineralization of the waste are increased, which may represent future earnings in terms of fertility and timing of Eucalyptus nutrient demand. Moreover, the productivity of eucalyptus is slightly higher in mixed stands compared to pure crop species, where the number of plants is twice bigger than the component crops.

The highest quantity of litter accumulated in eucalypt plantations $\left(16.6 \mathrm{t} \cdot \mathrm{ha}^{-1}\right.$ ) shows that the high contribution of timber (branches) to the produced litter may be increasing the mean residue decomposition in soil. This fact was probably influenced by the higher $\mathrm{N}$ contribution through leguminous litter, increasing the decomposition rate of existing waste on the soil from both legumes and eucalyptus.

Aiming to answer the questions about what types of land use systems have better functioning of soil and nutrient production, when submitted to different types of slashing and burning vegetation treatments associated to climate seasonality, this research has an objective to evaluate the nutrients content dynamic in different forestry and agroforestry systems in the city of Bragança, State of Pará.

\section{MATERIALS AND METHODS}

\subsection{Study Site}

The research was developed in the location of Benjamin Constant, city of Bragança, occupying Tijoca and Urumajó river valleys, and it was located in the east of the Bragantine zone and $25 \mathrm{~km}$ southeast of the city of Bragança [11] on geographical coordinates of $01^{\circ} 11^{\prime} 22^{\prime \prime}$ south latitude and of $46^{\circ} 40^{\prime} 41^{\prime \prime}$ west Greenwich longitude.

The studied area presents on its surroundings secondary forests of different ages, as well as areas with recent history of deforestation and similar use. Benjamin Con- 
stant community, belonging to smallholders, which was defined Land Unity 1 (UA) and is about 40 years old, contains a total area of 150 ha. These unities were previously selected through social-economic diagnosis performed in 1999, in five cities of the region. They are from successive cycles of slashing and burning, cropping and fallowing procedures with cotton cultivation (Gossypium hirsutum), rice (Oryza sativa), beans (Phaseolus vulgares), tobacco (Nicotiana tabacum), cassava (Manihot esculento) and corn (Zea mays) (Figure 1).

\subsection{Characterization of the Physical Environment}

\subsubsection{Climatology of the Region}

According to Climatological Normals of the Meteorology National Institute (INMET, 1992), the climate classification based on Thornthwaite and Mather (1955) to Bragança features an AwA'a' climate-type: in other words, a super humid megathermal climate with moderate water deficit during the August-December period. The air temperature presents a small annual variation in the Bragantina micro region. The daily temperature ranges may be higher than $10^{\circ} \mathrm{C}$, mainly during the drought season of the region. The average monthly relative humidity is always high, with a variation between a minimum of $77 \%$ and a maximum of $91 \%$. The annual rainfall varies between $2.200 \mathrm{~mm}$ to $3.000 \mathrm{~mm}$. The insolation is about 2.200 to 2.400 hours/year. There is a predominant direction of winds at the $\mathrm{N}$ or $\mathrm{NE}$ and an average annual evaporation of $50.1 \mathrm{~mm}$ [12].

It can be observed the existence of two periods with different characteristics regarding the distribution of rainfall, with a rainy station, which goes from January to June, and another dry station, which goes from July to December. On this study, February to June represented the rainy station and August to December the dry station.

In the city of Tracuateua (part of the Bragantina micro region, in the northeast of Pará) closer to Bragança by the distance of $17 \mathrm{~km}$, is located a meteorological tower of $25 \mathrm{~m}$ high, which belongs to INMET/Pará where daily data are collected on precipitation and temperature. These data meteorological were provided to this work.

\subsubsection{Soil and Topography}

Bragança is located on a plain area, formed by recent sediments, softly undulating, and has the maximum slope of $26 \mathrm{~m}$. The main river of the area is Caeté (Rocque 1982). The soils are acid and strongly acid, of good drainage because they are permeable and it presents low fertility because they are Yellow Latosol [12]. The preva-

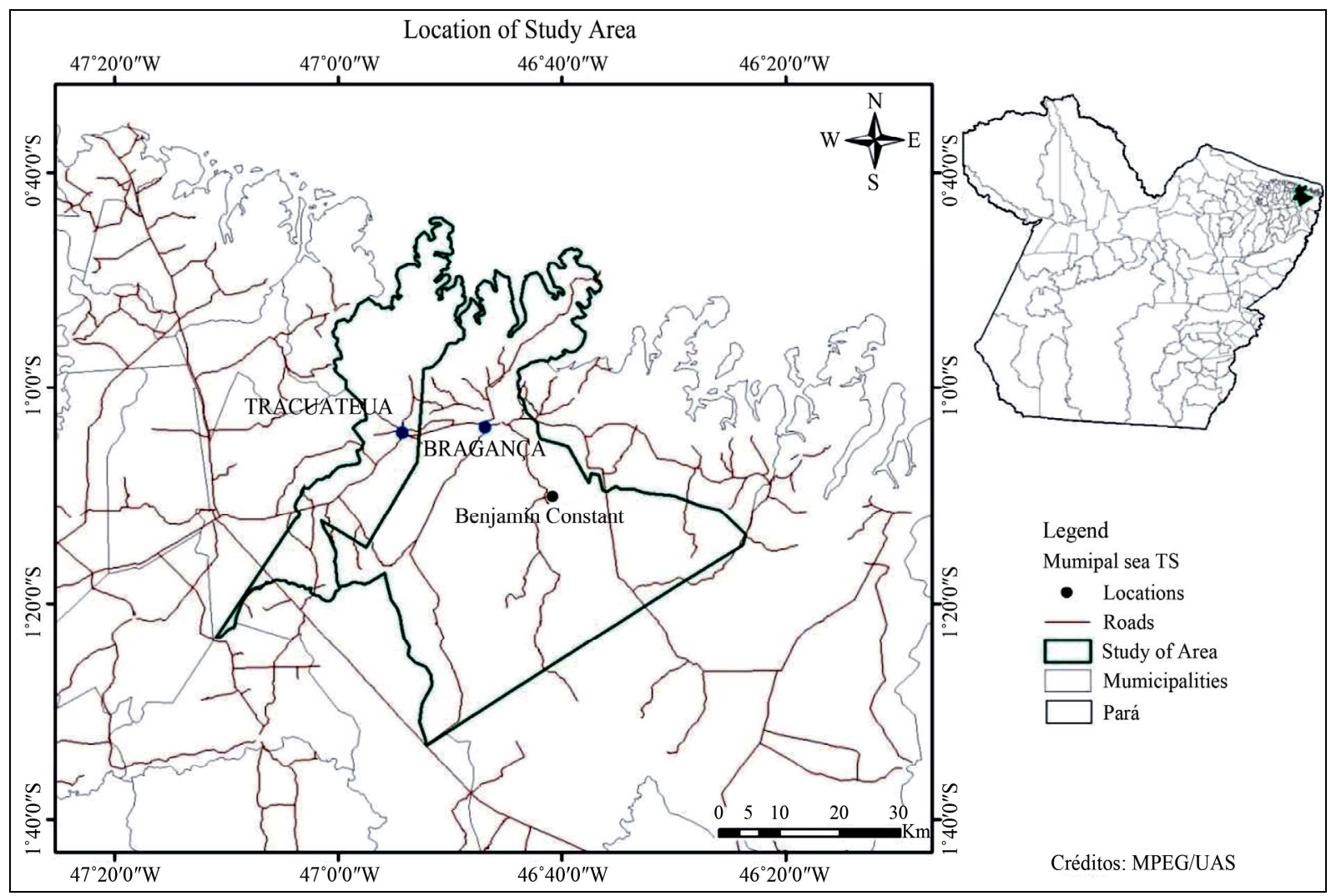

(Source: UAS, Emílio Goeldi Pará Museum, September 2010).

Figure 1. Location map of Benjamin Constant, city of Bragança-PA. 
lence is upland soil, which also shows some mangrove, hydromorphic and alluvial soils near the coast.

\subsubsection{Characterization of the Vegetation}

Nowadays, the main original vegetation types of the Bragantina zone, primary forest land, forest and permanently flooded lowland, upland fields and wetlands, have a very sparse occurrence, limited to a few places. The main landscape is characterized by a secondary vegetation with different ages and different degrees of plant succession, agricultural crops and grazing areas [10], from successive cycles of slashing and burning, cropping and fallowing procedures. According to [11], the type of vegetation in the region is secondary tropical rain forest.

The vegetation of Benjamin Constant community is similar to the vegetation of the coastal plain of the city of Bragança. In this location, "capoeiras" are at different stages of succession, buritizais, Açai Palm and vegetation characteristic of floodplains flooded. For the agricultural communities of Bragança, the "capoeiras" represents $79 \%$ of land use for the subsistence, while $6 \%$ of the stream, $13 \%$ of crop (whether annual, semi and perennial) and $2 \%$ of grasslands are used as other forms of income [13].

\subsection{Agroforestry in Areas of Secondary Forest Managed with Burning}

This enrichment study of capoeira with fruit (açaí, cupuaçu) paricá and legume cover was deployed in the area of family producer, which is constituted of 30-year-old secondary vegetation, and it was previously used with subsistence farming system with slashing and burning procedures.

The agroforestry system from secondary forest areas, where there have been slashing and burning procedures of the secondary vegetation since 1999, was determined as agroforestry systems with burning and it was used the preparation area with traditional slashing and burning procedures practiced by the local producer, so the secondary vegetation was slashed to and burned to implement paricá (Schizolobium amazonicum Huber ex Ducke), Açaí (Euterpe oleracea Mart), Cupuaçu (Theobroma grandiflorum Schum). Paricá plants and açaí were implanted with a $3 \mathrm{~m} \times 3 \mathrm{~m}$ space, and cupuaçú with a $8 \mathrm{~m}$ $\times 8 \mathrm{~m}$ space.

\subsection{Agroforestry System in Areas of Secondary Forest without Burning Procedures}

The agroforestry system, inside the Secondary Forest area were no burning procedure was performed, was determined as agroforestry systems without burning (SAFSQ), and the area preparation occurred during the same period and consisted of thinning the secondary vegetation to implant Paricá (Schizolobium amazonicum Huber ex. Ducke), Açaí (Euterpe oleracea Mart), and Cupuaçú (Theobroma grandiflorum Schum). Then it was proceeded with green manure cover Chamaecrista rupens, which was cut at the time of its flowering process, leaving the plant biomass on soil. Paricá plants and açaí were implanted with a $3 \mathrm{~m} \times 3 \mathrm{~m}$ space, and cupuaçú with a 8 $\mathrm{m} \times 8 \mathrm{~m}$ space.

\subsection{Collection and Treatment of Litter}

The collection of litter was made during the months of March (wet season) and November (dry season) 2009 using square collectors $\left(0.25 \times 0.25 \mathrm{~m}^{2}\right)$ put directly on the soil and stored in paper bags on the field. Then samples were placed in an oven at a temperature of $80^{\circ} \mathrm{C}$ during $72 \mathrm{~h}$. After drying, this material was crushed separately in a Wiley type mill, wrapped in plastic and stored in a dry place. Subsequently, the material was sent to EMBRAPA/CPATU/PARÁ Laboratory of Soil and Plant Tissue and Chemical Analysis Laboratory Emilio Goeldi Pará Laboratory, LAQ/GOELDI, where the samples were chemically analyzed for macro and micro nutrient content.

\subsection{Determination of the Analysis}

The samples were taken to the lab and reunited in 12 groups, and each group of samples with three repetitions was separated and homogenized to contain a sample. $1 \mathrm{~g}$ samples of vegetal material were weighted for the chemical analysis.

The determination of nitrogen was based on the method of micro-Kjeldahl, described in [14] which consists, basically, in steam distillation and titration using boric acid and sulfuric acid $0.05 \mathrm{~N}$ dye (fixative). It was added $2 \mathrm{ml}$ of digesting solution ( $2 \mathrm{~g}$ selenium powder to 1 liter of $\mathrm{H}_{2} \mathrm{SO}_{4}$ ) at the temperature of $400^{\circ} \mathrm{C}$, during 60 min, until the obtainment of the clear digested. After being cold, put $10 \mathrm{ml}$ of boric acid solution (distilled water and $80 \mathrm{~g}$ of boric acid) and add 5 drops of methyl red. In the still, add $10 \mathrm{ml}$ of soda, and when the sample reaches the blue coloration it can be taken out of the distiller. Lead elemeyer to the automatic burette, where titration is done for reading, until the color pink is achieved.

For the calculation of nitrogen, we used the following equation:

$$
V g-P B \times F \times 0.14
$$

$V g=$ amount spent; $P B=$ test blank; $F=$ factor; $0.14=$ constant.

The determination of phosphorus, potassium, calcium, magnesium, sodium, copper, manganese, iron and zinc was performed by acid digestion of the samples, and it 
was used $8 \mathrm{ml}$ of nitric acid and $2 \mathrm{ml}$ of perchloric acid, with the temperature of $180^{\circ} \mathrm{C}$ during $45 \mathrm{~min}$ to obtain the clear digested. After the acid digestion and the steps of the distilled water process, it was used $2 \mathrm{ml}$ solution of ammonium vanadate and ammonium molybdate in a $1: 1$ ratio.

After pipetting $8 \mathrm{ml}$ of the mineralized extract and 8 $\mathrm{ml}$ of each point on the curve $(0,2.5,5,7.5$ and 10$)$, the reading of the phosphorus is made using a spectrophotometer at a wavelength of $440 \mathrm{~nm}$. For the determination of sodium and potassium in a flame spectrophotometer, it is implemented a pattern of $10 \mathrm{ml}$ of sodium and $10 \mathrm{ml}$ of potassium in the same flask to measure with distilled water.

The readings of calcium, magnesium, copper, manganese, iron and zinc were determined by atomic absorption (Spectr AA-220-Atomic Absortion Spectrometer) following the methodology [15].

For the determination of calcium was added to $2 \mathrm{ml}$ of solution of lanthanum in $0.2 \mathrm{ml}$ of digested extract, where the analysis is done by electronic absorption, and it was used as a reference point for the gas mixture, the standard point of $2 \mathrm{ppm}$ of calcium. For determination of magnesium was added to $8 \mathrm{ml}$ of lanthanum, and it was added $0.2 \mathrm{ml}$ of the diluted sample, so it was used as a reference for the gas mixture the standard point of 0.5 ppm of magnesium, when the analysis was done by atomic absorption.

The analysis for iron, manganese, copper, and zinc by atomic absorption equipment were made by direct determination of the elements in nitric-perchloric extract in an atomic absorption spectrophotometer without interference problems or ionization using the hollow cathode lamp of the element [16]. It is recommended to analyze the standard curve previously for each quoted item. To The determination of the curves of iron and manganese was added $20 \mathrm{ml}$ of the standard of $100 \mathrm{ppm}$ of iron and $20 \mathrm{ml}$ of the standard of $100 \mathrm{ppm}$ of manganese. Pipette $0,1,2,3,4,5 \mathrm{ml}$ of the standard of $100 \mathrm{ppm}$ of manganese in six $100 \mathrm{ml}$ flasks. Ascertain with demineralized water. The curve points are for both iron and manganese to $0,1,2,3,4$ and 5 ppm.

To the determination of the curves of copper and zinc and manganese was added $20 \mathrm{ml}$ of the standard of 100 ppm of copper and $20 \mathrm{ml}$ of the standard of $100 \mathrm{ppm}$ of zinc. Pipette $0,1,2,3,4,5 \mathrm{ml}$ of the standard of 100 ppm of copper in six $100 \mathrm{ml}$ flasks. Ascertain with demineralized water. The curve points are for both the copper and zinc, $0,0.1,0.2,0.3,0.4$, and $0.5 \mathrm{ppm}$.

\section{STATISTICAL ANALYSIS}

The statistical analysis of data obtained from the laboratory results were subjected to analysis of variance, average test and Tukey test at 5\% probability, using SAS software version 8.2.

\section{RESULTS AND DISCUSSION}

\subsection{Concentration of Macronutrients in Litter}

Nitrogen (Figure 2(a)) was the element with the highest concentration of all the nutrients analyzed, with a maximum value of $18.95 \mathrm{~g} \cdot \mathrm{Kg}^{-1}$ followed by calcium (Figure 3(a)) showed that the maximum value of 10.76 $\mathrm{g} \cdot \mathrm{Kg}^{-1}$, both in the rainy season. These elements were also the only ones who did not show significant differences between treatments with burning in the rainy season and dry without burning in the rainy and dry seasons. Statistical differences were presented (Tukey's test, $p<$ $0.05)$, especially between agroforestry systems with burning for the elements phosphorus (Figure 2(b)), magnesium (Figure 3(b)), potassium (Figure 4(a)), and sodium (Figure 4(b)) as presented differences in the same treatment during different time periods. Considering the two systems, the nutrient concentration was observed in decreasing order: $\mathrm{N}>\mathrm{Ca}>\mathrm{Mg}>\mathrm{Na}>\mathrm{K}>\mathrm{P}$, all with maximum values during the rainy season, with the exception of $\mathrm{Mg}$ with the highest concentration in the dry season.

There were significant differences in nitrogen and phosphorus (Figures 2(a) and (b)) between treatments with and without burning during the dry and rainy, with highest value observed in the rainy season agroforestry systems agroforestry systems and agroforestry systems with burning, $18.95 \mathrm{~g} \cdot \mathrm{Kg}^{-1}$ and $0.35 \mathrm{~g} \cdot \mathrm{Kg}^{-1}$, respectively. However, magnesium (Figure 3(b)) was significantly higher in agroforestry systems with burning in the dry season $\left(7.45 \mathrm{~g} \cdot \mathrm{Kg}^{-1}\right)$, we observed a significant reduction of $60 \%$ in the magnesium concentration. The elements phosphorus and potassium (Figures 2(b) and 4(a)) showed lower concentrations in both treatments agroforestry systems with burning and without burning and two seasons (dry and rainy), with a maximum value of 0.35 $\mathrm{g} \cdot \mathrm{Kg}^{-1}$ and $0.5 \mathrm{~g} \cdot \mathrm{Kg}^{-1}$, respectively, both in the rainy season.

Were observed between treatments with burning and without burning in the dry season and rainy that there was no statistically significant difference in calcium concentrations observed in (Figure 3(a)), with a variation in the range of $\left(7.34 \mathrm{~g} \cdot \mathrm{Kg}^{-1}\right.$ to $\left.10.76 \mathrm{~g} \cdot \mathrm{Kg}^{-1}\right)$. All elements showed high concentrations significantly different $(p<$ 0.05 ) with the exception of $\mathrm{Ca}$, which was the only element that did not show statistically significant differences for all treatments and periods, it can be said that this element did not vary as a function seasonal climate.

It was observed in (Figure 4(b)), which showed a higher sodium concentration agroforestry systems with burning in the dry season and the rainy season in agro- 


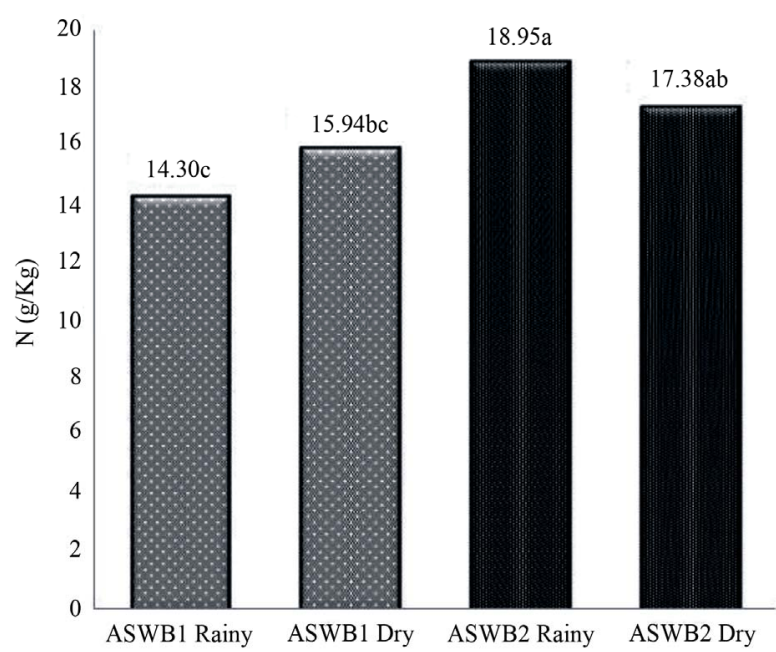

(a)

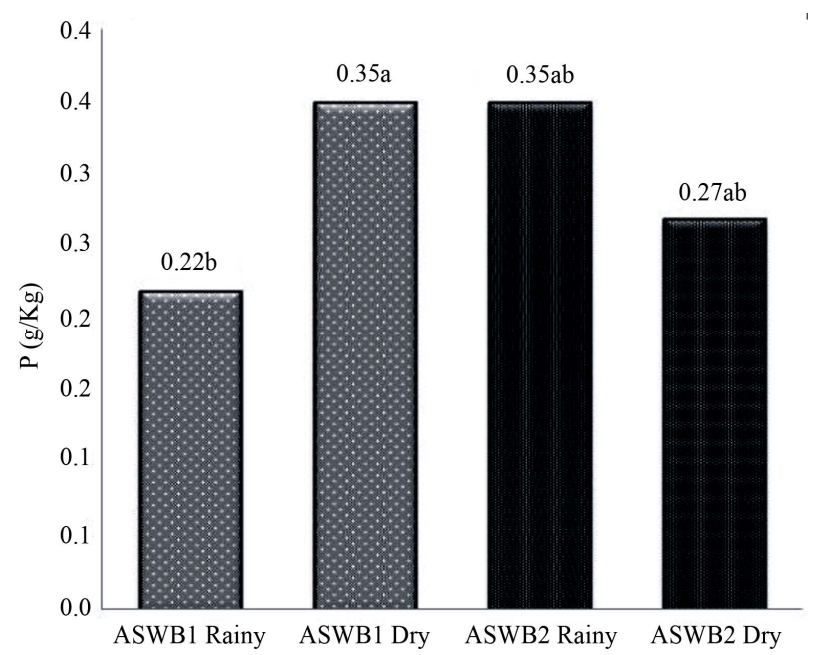

(b)

ASWB1 Rainy; ASWB2 Rainy; ASWB1 Rainy; ASWB2 Rainy; ASWB1 Dry; ASWB2 Dry; - ASWB1 Dry; ASWB2 Dry. Means followed by lowercase lines, do not differ statistically by $\mathrm{F}$ test and Tukey at $5 \%$ probability. $\mathrm{N}=$ nitrogen, $\mathrm{P}=$ phosphorus. Agroforestry systems with burning-ASWB1. Agroforestry systems without burning-ASWB2.

Figure 2. Concentration N (a) and P (b), in litter under agroforestry systems managed with burning and no burning, community Benjamin Constant, Bragança-PA for the year 2009.

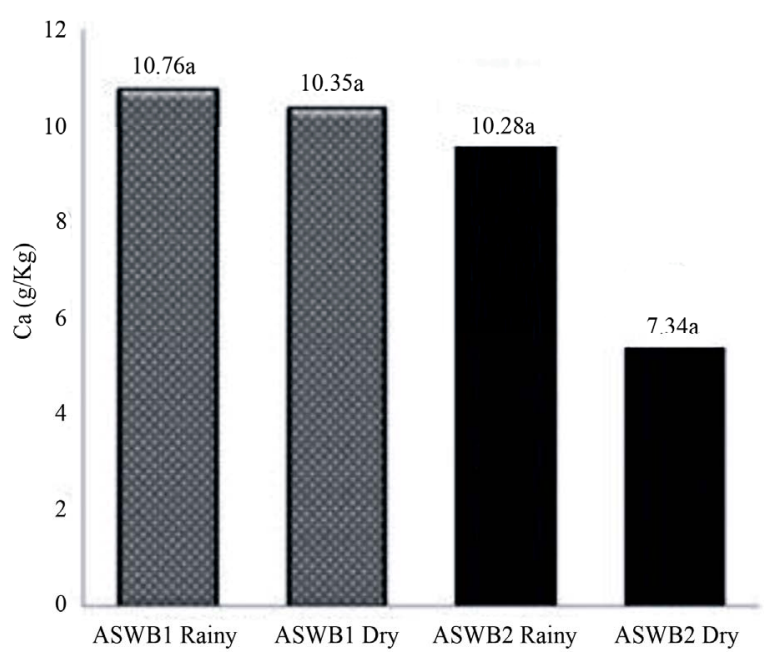

(a)

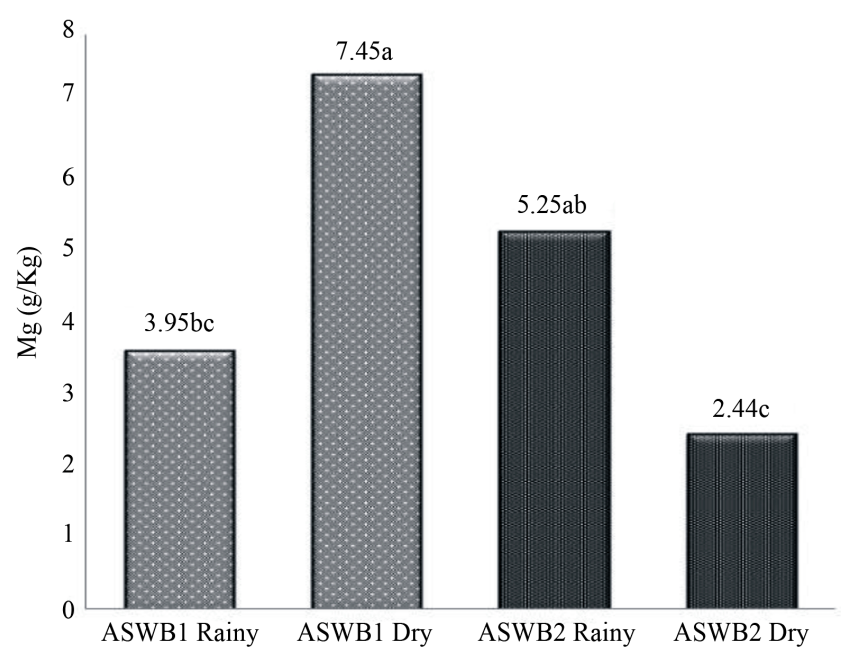

(b)

\footnotetext{
ASWB1 Rainy; ASWB2 Rainy; ASWB1 Rainy; ASWB2 Rainy; ASWB1 Dry; ASWB2 Dry; ASWB1 Dry; - ASWB2 Dry. Means followed by lowercase lines, do not differ statistically by $\mathrm{F}$ test and Tukey at $5 \%$ probability. Ca $=$ calcium, Mg $=$ magnesium. Agroforestry systems with burning-ASWB1. Agroforestry systems without burning-ASWB2
}

Figure 3. Concentration $\mathrm{Ca} \mathrm{(a)} \mathrm{and} \mathrm{Mg}$ (b), in litter under agroforestry systems managed with burning and no burning, community Benjamin Constant, Bragança-PA for the year 2009.

forestry systems without burning, both treatments decreased significantly by $37 \%$ and $32 \%$, respectively. However, magnesium (Figure 3(b)), also showed the same pattern in nutrient concentration was higher in with burning in the dry season and without burning in the rainy season, the two treatments showed significant reduction of $48 \%$ and $46 \%$ respectively. Potassium showed higher concentration with burning during the dry period and agroforestry systems without burning during the rainy season, with maximum values of 1.90 and 1.96 $\mathrm{g} \cdot \mathrm{Kg}^{-1}$ and minimum values $0.5 \mathrm{~g} \cdot \mathrm{Kg}^{-1}$ one and 0.74 , respectively.

Considering only one type of treatment agroforestry systems with burning, with the exception of calcium, all elements analyzed showed reduction in the concentrations of nutrients in the rainy season, except calcium. There was a reduction of the nitrogen of 18.95 to 14.39 $\mathrm{g} \cdot \mathrm{Kg}^{-1}$; phosphorus decreased from 0.35 to $0.22 \mathrm{~g} \cdot \mathrm{Kg}^{-1}$; potassium decreased from $1.9 \mathrm{~g} \cdot \mathrm{Kg}^{-1}$ to $0.5 \mathrm{~g} \cdot \mathrm{Kg}^{-1}$; magnesium reduced from 7.45 to $3.59 \mathrm{~g} \cdot \mathrm{Kg}^{-1}$ and sod- 


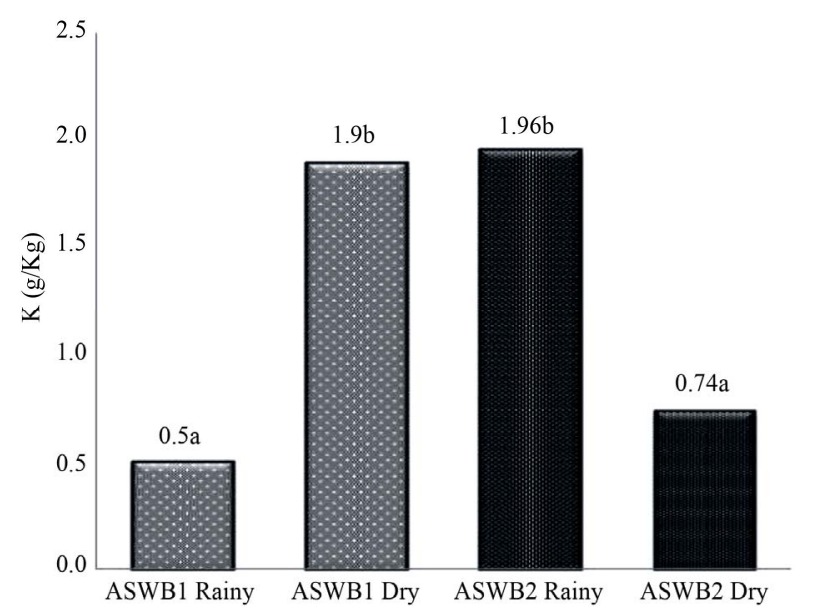

(a)

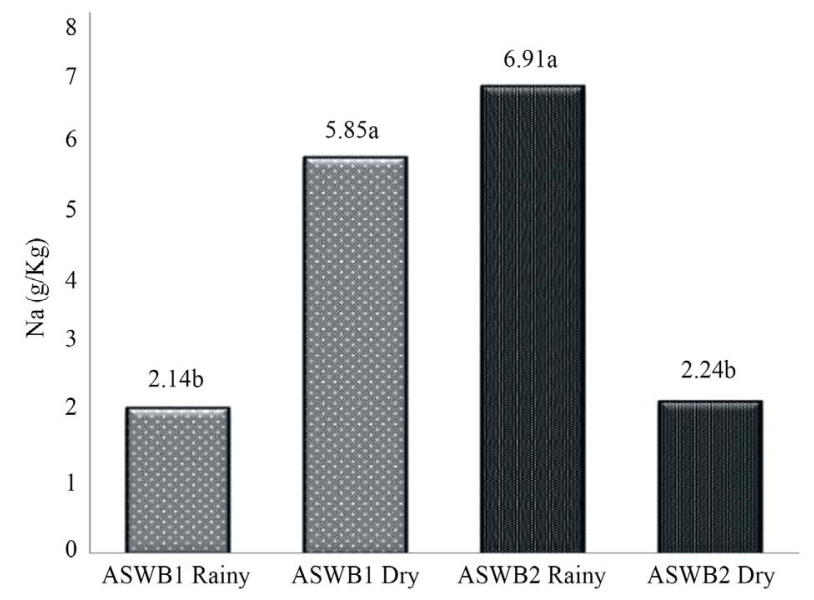

(b)

ASWB1 Rainy; ASWB2 Rainy; ASWB1 Rainy; ASWB2 Rainy; ASWB1 Dry; ASWB2 Dry; ASWB1 Dry; ASWB2 Dry. Means followed by lowercase lines, do not differ statistically by F test and Tukey at $5 \%$ probability. $\mathrm{K}=$ potassium, $\mathrm{Na}=$ sodium. Agroforestry systems with burning-ASWB1. Agroforestry systems without burningASWB2.

Figure 4. Concentration $\mathrm{K}$ (a) and $\mathrm{Na}$ (b), in litter under agroforestry systems managed with burning and no burning, community Benjamin Constant, Bragança-PA for the year 2009.

dium of $5.85 \mathrm{~g} \cdot \mathrm{Kg}^{-1}$ and $2.14 \mathrm{~g} \cdot \mathrm{Kg}^{-1}$.

Agroforestry systems without burning in the concentration of nutrients was opposite to that observed in agroforestry systems with burning because all elements analyzed showed a reduction in the concentrations of nutrients in the dry season. A reduction in nitrogen of 18.95 to $17.38 \mathrm{~g} \cdot \mathrm{Kg}^{-1}$; phosphorus decreased from 0.35 to 0.27 $\mathrm{g} \cdot \mathrm{Kg}^{-1}$, potassium decreased from 1.96 to $0.74 \mathrm{~g} \cdot \mathrm{Kg}^{-1}$; calcium decreased from 10.28 to $7.34 \mathrm{~g} \cdot \mathrm{Kg}^{-1}$ magnesium decreased from 5.25 to $2.44 \mathrm{~g} \cdot \mathrm{Kg}^{-1}$, and sodium decreased from 6.91 to $2.24 \mathrm{~g} \cdot \mathrm{Kg}^{-1}$, with differences shown (Tukey, $p<0.5$ ).

Treatment agroforestry systems without burning rainy and dry season had the highest concentrations of nutri- ents from litter, for the elements: $\mathrm{N}, \mathrm{P}, \mathrm{K}, \mathrm{Mg}, \mathrm{Na}$, and the only element with the highest concentration in the treatment agroforestry systems with burning was rainy calcium.

\subsubsection{Influence of Seasonality}

The average annual rainfall (Figure 5) showed higher values in May $(849.7 \mathrm{~mm})$ and lowest values in October and November, months when there was no rainfall $(0$ $\mathrm{mm})$, and the annual average was $(2.323 \mathrm{~mm})$, considering the year of the experiment and the average of the last 20 years. Precipitation was a variable that was shown to have influenced the concentration of these nutrients. In the rainy season the highest levels of rainfall in the region were observed in the months of February, March, April and May, with a high peak in May, presented differently in rainfall over the last 10 years, and in 1995 presented the highest value registered in rainfall (657.20 $\mathrm{mm})$, and the average for the month of May for the last 20 years is $(347.6 \mathrm{~mm})$.

Although rainfall make the incorporation of nutrients in plants, for agroforestry systems with burning, it was observed that the reduction in concentration of these nutrients in the rainy season. The litter is characterized by presenting a greater quantity of production during the dry period, the decomposition rate and nutrient concentrations are lower. The monthly average temperature showed higher values in December $\left(27.7^{\circ} \mathrm{C}\right)$ and lowest values in April $\left(25.2^{\circ} \mathrm{C}\right)$, with an annual average of $26.42^{\circ} \mathrm{C}$.

The results of the analysis of macronutrients in the litter are presented in (Table 1). The average values for nitrogen $(\mathrm{N})$ presented in the area of agroforestry system with burning procedures agroforestry systems with burning was (15.94 $\left.\mathrm{g} \cdot \mathrm{Kg}^{-1}\right)$, and without burning procedures in the agroforestry system without burning ranged from $\left(17.38 \mathrm{~g} \cdot \mathrm{Kg}^{-1}\right)$, so the average nitrogen $(\mathrm{N})$ was higher during the rainy season. No statistical difference between the periods considered occurred. For the analysis of the average litter the average of the nutrient phosphorus $(\mathrm{P})$ and potassium $(\mathrm{K})$ were $\left(0.35\right.$ and $\left.1.90 \mathrm{~g} \cdot \mathrm{Kg}^{-1}\right)$, respectively. Considering the same area there was statistical difference in different periods for potassium (K), however, the agroforestry systems with burning and the agroforestry systems without burning for the same period had no difference. Phosphorus (P) and potassium (K) had higher concentrations of nutrients during the rainy season, in the area agroforestry systems without burning.

The variation analysis of calcium (Ca) was (7.34 $\mathrm{g} \cdot \mathrm{Kg}^{-1}$ to $\left.10.76 \mathrm{~g} \cdot \mathrm{Kg}^{-1}\right)$, and there was no differ between areas and periods. Magnesium $(\mathrm{Mg})$ and sodium $(\mathrm{Na})$, showed differences between areas, periods, but considering the different areas during the dry season and the rainy season, there was no difference.

The data analysis of macronutrients in the litter, on a 
Table 1. Concentrations of nutrients from litter in agroforestry system with burning and agroforestry system without burning in the rainy season and the dry season, the community Benjamin Constant, Bragança-PA for the year 2009.

\begin{tabular}{ccccccc}
\hline Elemento & $\mathrm{N}$ & $\mathrm{P}$ & $\mathrm{K}$ & $\mathrm{Ca}$ & $\mathrm{Mg}$ & $\mathrm{Na}$ \\
\hline \multicolumn{7}{c}{$(\mathrm{g} / \mathrm{Kg})$} \\
$\mathrm{N}$ & 1 & & & & & \\
$\mathrm{P}$ & 0.391632 & 1 & & & & \\
$\mathrm{~K}$ & 0.518017 & $0.800401^{*}$ & 1 & & & \\
$\mathrm{Ca}$ & -0.25408 & -0.21573 & -0.06653 & 1 & & \\
$\mathrm{Mg}$ & -0.13698 & 0.131755 & 0.118806 & 0.197858 & 1 & \\
$\mathrm{Na}$ & 0.310008 & 0.174853 & 0.541457 & 0.237893 & 0.351254 & 1 \\
\hline
\end{tabular}

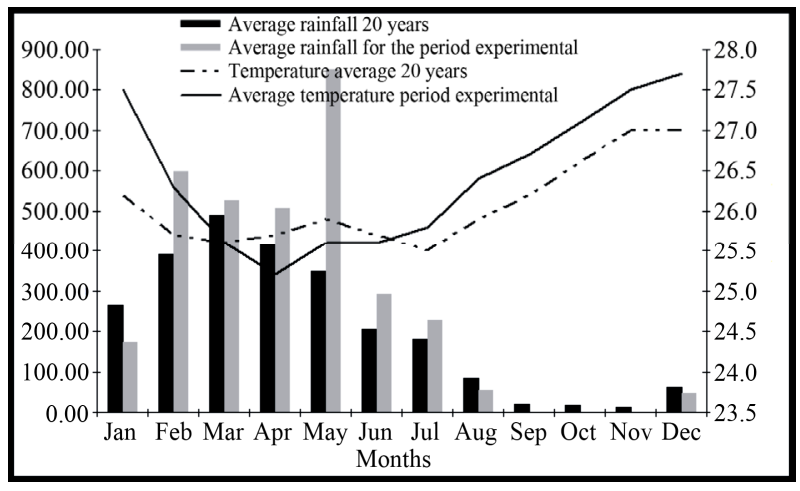

Figure 5. Monthly variation of precipitation and temperatures during the studied period (2009), $17 \mathrm{~km}$ distant tower of the studied area. Data provided by the Meteorology National Institute INMET/PARÁ.

gener alway, presented a higher average total in the agroforestry system area without burning procedures without burning for $\mathrm{N}, \mathrm{P}, \mathrm{K}, \mathrm{Ca}, \mathrm{Na}$, respectively, $30.24 \mathrm{~g} \cdot \mathrm{Kg}$; $0.57 \mathrm{~g} \cdot \mathrm{Kg}, 2.40 \mathrm{~g} \cdot \mathrm{Kg}, 21.11 \mathrm{~g} \cdot \mathrm{Kg}, 7.99 \mathrm{~g} \cdot \mathrm{Kg}$; and the agroforestry system with burning procedures, for $\mathrm{N}, \mathrm{P}, \mathrm{K}$, $\mathrm{Ca}, \mathrm{Na}$, except for the magnesium $(\mathrm{Mg})$, which presented the total amount of $(11.04 \mathrm{~g} \cdot \mathrm{Kg})$. Considering the rainy and dry seasons, only calcium showed a higher content of nutrients in the two periods, and the content of $(\mathrm{Mg})$ and sodium $(\mathrm{Na})$ was higher only during the dry season.

The average concentrations of nitrogen, phosphorus, potassium, magnesium and sodium were significantly higher during the rainy season in the agroforestry system without burning procedures agroforestry systems without burning except for the calcium. During the drought period were significantly higher only the average values for concentrations of nitrogen and potassium: for nitrogen $17.38 \mathrm{~g} \cdot \mathrm{Kg}^{-1}$ and potassium $0.61 \mathrm{~g} \cdot \mathrm{Kg}^{-1}$. After all the macro nutrients studied, the highest concentrations were of nitrogen and for the two systems agroforestry with burning and without burning, in both periods (dry season and rainy season), as (Table $\mathbf{1}$ ).

\subsubsection{Interaction between Macronutrients Litter in an Agroforestry System Managed with Burning and without Burning}

In general, among all the elements analyzed, only the Phosphorus and Potassium showed high positive and significant correlation (Figure 6) in the concentration of nutrients in the litter $(r=0.80)$ in agroforestry systems with burning. It is observed that with increasing phosphorus concentration increased there was a potassium concentration, as well as nitrogen, these elements are also required in larger quantities by plants.

\subsubsection{Concentration of Micronutrients in Litter}

The elements $\mathrm{Cu}$ and $\mathrm{Zn}$ (Figures 7(a) and 8(b)) showed the lowest concentrations and did not show any significant variation in treatment, with the following order of concentration: Fe $\left(1051.3 \mathrm{mg} \cdot \mathrm{Kg}^{-1}\right)>\mathrm{Mn}(273.62$ $\left.\mathrm{mg} \cdot \mathrm{Kg}^{-1}\right)>\mathrm{Zn}\left(33.87 \mathrm{mg} \cdot \mathrm{Kg}^{-1}\right)>\mathrm{Cu}\left(28.78 \mathrm{mg} \cdot \mathrm{Kg}^{-1}\right)$. For $\mathrm{Cu}$ and $\mathrm{Mn}$, agroforestry systems without burning, with higher concentrations during drought and agroforestry systems without burning, higher concentrations in the rainy season. For the elements $\mathrm{Fe}$ and $\mathrm{Zn}$, in with burning showed higher concentrations in the rainy season and without burning only Fe showed higher concentrations in the dry season. The wide range of micronutrients found between higher and lower amount of nutrients in this study was $\left(19.59 \mathrm{mg} \cdot \mathrm{Kg}^{-1}\right.$ to $\left.1051.3 \mathrm{mg} \cdot \mathrm{Kg}^{-1}\right)$ in the elements $\mathrm{Cu}$ and $\mathrm{Fe}$, respectively.

Analyzing the concentrations of nutrients in general scale, it is observed that copper and iron had the highest concentrations in agroforestry systems without burning in drought, and agroforestry systems with burning had higher nutrient concentrations in the rainy season the element copper and manganese, zinc showed no seasonal variation. Although had the highest concentrations, the elements $\mathrm{Mn}$ and Fe showed significant differences only between the different treatments and not between periods, the elements copper and zinc did not differ between treatments and periods (Figures 7(a) and (b)).

Some authors together bibliographical review in different forests of the world, on the nutrient content of the litter and concluded that the availability of soil water increases the concentration of nutrients in forest, but in agroforestry systems precipitation removes nutrients. In this study, the rainy season had the highest concentrations of nutrients in the litter. Litter production varies between fractions, perhaps this interferes with nutrient content (Figure 8).

According [17], the decomposition rate is highest in the shoot and the greater availability of water in the soil higher decomposition. In this study, the greatest amount of litter collected in agroforestry, were branches or twigs, which have a lower decomposition rate of the resistance of the plant material, thus being able to influence the 


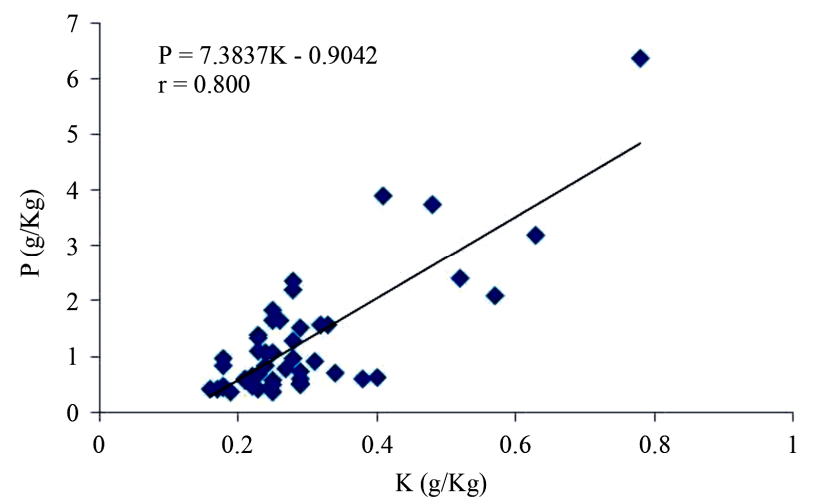

Figure 6. Correlation between soil $\mathrm{P}$ and $\mathrm{K}$ nutrient concentrations in litter in agroforestry systems and burns without burning, community Benjamin Constant Bragança—Pará.

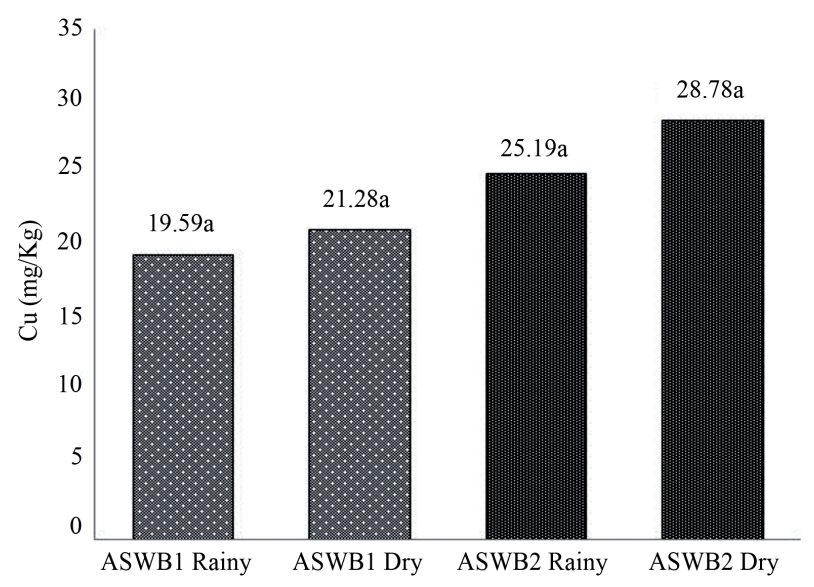

(a)

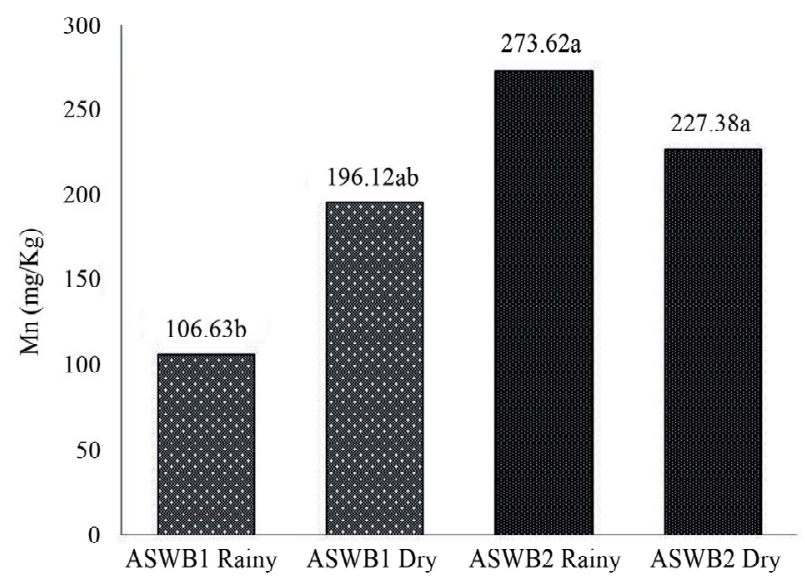

(b)

\begin{abstract}
ASWB1 Rainy; ASWB2 Rainy; ASWB1 Rainy; ASWB2 Rainy; ASWB1 Dry; ASWB2 Dry; ASWB1 Dry; ASWB2 Dry. Means followed by lowercase lines, do not differ statistically by F test and Tukey at $5 \%$ probability. $\mathrm{Cu}=$ copper; $\mathrm{Mn}=$ manganese. Agroforestry systems with burning-ASWB1. Agroforestry systems without burningASWB2.
\end{abstract}

Figure 7. Concentration $\mathrm{Cu}$ (a) and $\mathrm{Mn}(\mathrm{b})$, in litter under agroforestry systems managed with burning and no burning, community Benjamin Constant, Bragança-PA for the year 2009.

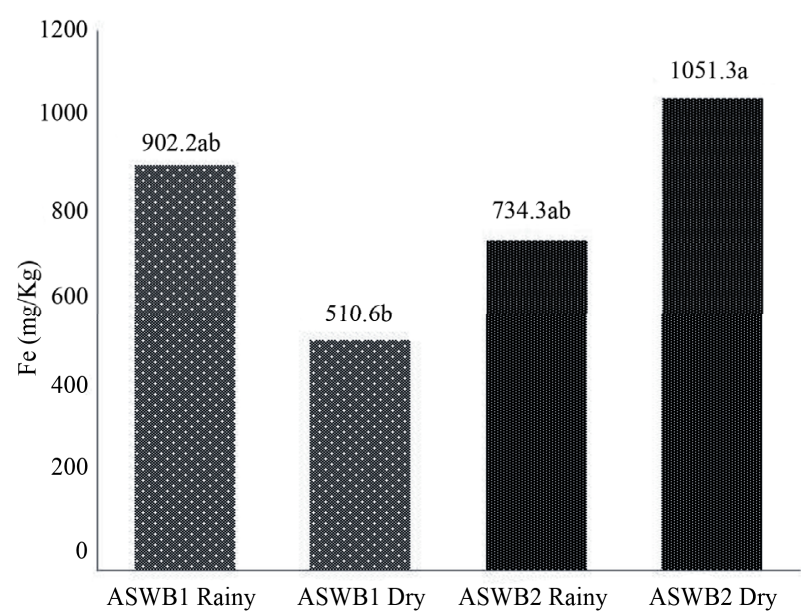

(a)

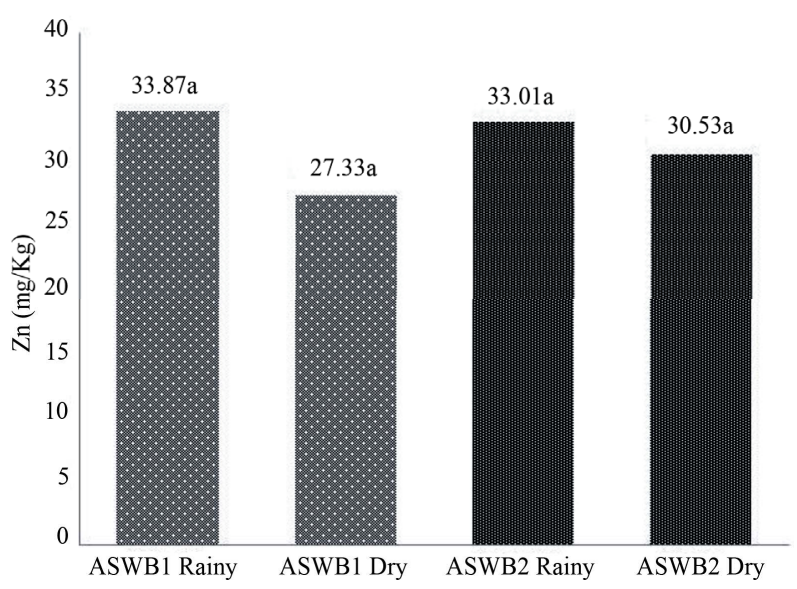

(b)

ASWB1 Rainy; ASWB2 Rainy; ASWB1 Rainy; ASWB2 Rainy; ASWB1 Dry; ASWB2 Dry; ASWB1 Dry; ASWB2 Dry. Means followed by lowercase lines, do not differ statistically by $\mathrm{F}$ test and Tukey at $5 \%$ probability. $\mathrm{Fe}=$ iron; $\mathrm{Zn}=$ zinc. Agroforestry systems with burning - ASWB1. Agroforestry systems without burning - ASWB2

Figure 8. Concentration $\mathrm{Fe}$ (a) and $\mathrm{Zn}$ (b), in litter under agroforestry systems managed with burning and no burning, community Benjamin Constant, Bragança-PA for the year 2009 .

total quantity of nutrients produced by the burlap. Then the $\mathrm{N}$, the element $\mathrm{Ca}$ showed the highest amount of nutrients in the two treatments, as the fraction of branches had the highest content of $\mathrm{Ca}$ [14] this large amount of $\mathrm{Ca}$ found in this study may be a consequence of the large amount of branches that was collected in this system. The high mobility of N, P and K may have contributed to high concentrations in the rainy season, influenced by seasonality. The highest concentration of $\mathrm{K}$ presented in the rainy season in without burning can be explained by the fact that this element be returned mainly by rainfall in the litter. This result may be due to the low mobility of calcium, due to its limited redistribution in the plant. The nutrient content of litter in this study followed the sequence: $\mathrm{N}>\mathrm{Ca}>\mathrm{K}>\mathrm{Mg}>\mathrm{P}$, similar to that observed 
by [18].

According [19] in a study conducted in an agroforestry system, the high concentrations found in leaves potassium inhibit calcium concentration, for this work the potassium concentration was lower than in calcium, besides differing from this result, it can to evaluate the low concentration of potassium may be due to low production of sheets that have been collected .

Agroforests system in the use of forest species or fruit, contributes beyond the regular cycling of other elements, also to increase the amount of nitrogen in the soil [20], this may explain the high concentration of nitrogen also found in this study, in which deployment was with fruit species.

In general, this study showed higher concentration of nutrients in the litter during the period of heavy precipitation. For [21] during periods of heavy precipitation could favor the absorption of certain nutrients by placing them fully available in all parts of the plants. For [12] in summer, due in part to the greater the physiological activity, increase the rates of allocation of nutrients, which contributes to the growth of the plant during that period and consequently increases the transport of nutrients within the plant.

Phosphorus is regarded as a very mobile plant, and in some species with senescence characteristics, there translocation from $40 \%$ to $60 \%$ of the leaves to other plant organs prior to leaf abscission [22], thus allowing this nutrient to be redistributed and used in the formation of new tissue. This mechanism is essential to ensure continued productivity in poor soils [23], as this study and the vast majority of tropical soils.

\section{CONCLUSION}

The total amount of macronutrients evaluated, is higher in agroforestry system without burning. In the rainy season the concentration of nutrients has greater seasonal variation between systems. The system where there was the burning seems to have been favored as the increase in the concentration of nutrients, but their concentrations in this system were presented in the dry season. The concentration of micronutrients has no seasonal influences.

\section{ACKNOWLEDGEMENTS}

To the National Council of Scientific and Technological Development/CNPq; the scholarship granted by the Postgraduate course in Agricultural Sciences/Federal Rural University of Amazon/UFRA; Emilio Goeldi Pará Museum (MPEG); and to the FAPESPA project/Edital $17 / 2008$.

\section{REFERENCES}

[1] Borém, R.A.T. and Ramos, D.P. (2002) Topographic and seasonal variation of nutrients in leaf litter of a fragment of rainforest. Core Review, 2, 42-059.

[2] Luizão, F.J., Tapia-Coral, S., Gallardo-Ordinola, J., Silva, G.C., Luizão, R.C., T Rujillo-Cabrera, L., Wandelli, E. and Fernandes, E.C.M. (2006) Biogeochemical cycles in the Amazon agroforestry. In: Gama-Rodrigues, A.C.D., Barros, N.F.D., Gama-Rodrigues, E.F.D., Freitas, M.S.M., Viana, A.P., Jasmin, J.M., Marciano, C.R. and Carneiro, J.G.D.A., Eds., Agroforestry: Scientific Basis for Sustainable Development, Embrapa Information Technology, Brasilia, 375, 87-100.

[3] Vital, A.R.T., Amaral, I.G., Frankent, W.K. and Fonseca, R.C.B. (2004) Litter production and nutrient cycling in a semideciduous forest in the riparian zone. Tree Review, $\mathbf{6}$, 793-800.

[4] Albrecht, A. and Kandji, S.T. (2003) Carbon sequestration in tropical agroforestry systems. Agriculture, Ecosystems and Environment, 99, 15-27.

http://dx.doi.org/10.1016/S0167-8809(03)00138-5

[5] Facceli, J.M. and Pickett, S.T.A. (1991) Plant litter: Its dynamics and effects on plant community structure. The Botanical Review, 57, 1-32.

http://dx.doi.org/10.1007/BF02858763

[6] Arato, H.D., Martins, S.V. and Ferrari, S.H. (2003) Production and decomposition of litter in agroforestry system deployed for recovery of degraded areas in Viçosa, MG. Tree Review, 27, 715-721.

[7] Silva, R.M. (2004) Influence of meteorological variables on litter production in Scientific Station Ferreira Penna, Caxiuanã, PA. Ph.D. Dissertation, Federal University of Viçosa, Brazil.

[8] Balieiro, F.C., Franco, A.A. and Pereira, M.G. (2004) Dynamics of litter and transfer of nitrogen to the soil in plantations Pseudosamanea guachapele and Eucalyptus grandis. Brazilian Agricultural Research, Brasília, 39, 597601.

[9] Rios, M., Martins-Da-Silva, R.C.V., Sabogal, C., Martins, J., Silva, R.N., Brito, R.R., Brito, I.M., Brito, M.F.C., Silva, J.R. and Ribeiro, R.T. (2001) Advantage of plants for caponier community Benjamin Constant, Pará, Brazilian Amazon. CIFOR, 54.

[10] Denich, M., Vlek, P., G., Sá, T.D.A., Vielhauer, K. and Lücke, W. (2005) Concept for the development of firefree fallow management in the Eastern Amazon, in Brazil. Agriculture Ecosystems \& Environment, 110, 43-58. http://dx.doi.org/10.1016/j.agee.2005.05.005

[11] Pereira, C.A. and Vieira, I.C.G. (2001) The importance of secondary forests and the impacts of its replacement by plantations mechanized grain Amazon. Interscience, 26, 337-341.

[12] Malavolta, E. (2006) Manual of plant mineral nutrition. Ceres, São Paulo, 638.

[13] Luizão, R.C. and Luizão, F.J. (1989) In: Scientific basis for development strategies and preservation of the Amazon: Facts and perspectives. Inpa-Manaus, 1, 65-75.

[14] Luizão, F.J. (2007) Nutrient cycling in the Amazon: Responses to environmental and climate changes. Science and Culture, 59, 31-36. 
[15] Embrapa. National Research Center of Soil (1997) Manual methods of soil analysis. Rio de Janeiro, 212.

[16] Schumacher, M.V., Brun, E.J., Hernandes, J.I. and Konig, F.G. (2004) Litter production in a forest of Araucaria angustifolia (Bertol) Kuntze in the city of Pinhal GrandeRS. Tree Review, 28, 29-37.

[17] Corrêa, F.L.O., Ramos, J.D., Gama-Rodrigues, A.C. and Muller, M.W. (2006) Litter production in multistrata agroforestry system in the State of Rondônia, Brazil. Science. Agrotecnica, 30, 1099-1105. http://dx.doi.org/10.1590/S1413-70542006000600008

[18] Luizão, F.J., Tapia-Coral, S., Gallardo-Ordinola, J., Silva, G.C., Luizão, R.C., Rujillo-Cabrera, L., Wandelli, E. and Fernandes, E.C.M. (2006) Biogeochemical cycles in the Amazon agroforestry. In: Gama-Rodrigues, A.C.D., Barros, N.F.D., Gama-Rodrigues, E.F.D., Freitas, M.S. M., Viana, A.P., Jasmin, J.M., Marciano, C.R. and Carneiro., J.G.D.A., Eds., Agroforestry: Scientific Basis for Sustainable Development. Embrapa Information Technology, Brasilia, 375, 87-100.

[19] Mackensen, J., Hölscher, D., Klinge, R. and Fölster, H. (1996) Nutrient transfer to the atmosphere by burning of debris in eastern Amazônia. Forest Ecology and Management, 86, 121-128.
http://dx.doi.org/10.1016/S0378-1127(96)03790-5

[20] Marenco, R.A. and Lopes, N.F. (2007) Plant physiology: Photosynthesis, respiration, water relations and mineral nutrition. Viçosa. 469.

[21] Vogel, H.L.M. (2005) Quantification of biomass and nutrients in a deciduous forest in Grand River southern, Brazil. Ph.D. Thesis, Federal University of Saint Mary, Grand River Southern.

[22] Mackensen, J., Hölscher, D., Klinge, R. and Fölster, H. (1996) Nutrient transfer to the atmosphere by burning of debris in eastern Amazônia. Forest Ecology and Management, 86, 121-128.

http://dx.doi.org/10.1016/S0378-1127(96)03790-5

[23] Shwendener, C.M., Lehmann, J., Camargo, P.B., Luizão, R.C.C. and Fernandes, E.C.M. (2004) Nitrogen transfer between high- and low-quality leaves on a nutrient-poor Oxisol determined by ${ }^{15} \mathrm{~N}$ enrichment. Soil Biology \& Biochemistry, 37, 787-794. http://dx.doi.org/10.1016/j.soilbio.2004.10.011

[24] Santana, J.A.S., Sousa, L.K.V.S. and Almeida, W.C. (2003) Annual litter production in a secondary forest in eastern Amazonia. Journal of Agricultural Sciences, 40, 119-132. 